\title{
The effect of carbonic anhydrase inhibitors on exercise at high altitude (Abstract)
}

\author{
J.H. Coote, A.R. Bradwell, M.H. Winterborn and I. Chesner \\ Department of Physiology, The Medical School, University of Birmingham, Edgbaston, Birmingham B15 2TH, \\ $U K$.
}

The effect of acetazolamide on exercise performance in 20 subjects was assessed before and during ascent to $4846 \mathrm{~m}$. Mean $\mathrm{VO}_{2}$ max at sea level was $52 \pm 2.6 \mathrm{ml} / \mathrm{kg}$ for subjects subsequently put on acetazolamide and $53 \pm 3.2 \mathrm{ml} / \mathrm{kg}$ for those subsequently put on placebo. Maximum heart rate (HR max) was determined using a standardized incremental work test to exhaustion. In a 15 minute work capacity test at $85 \% \mathrm{HR}$ max mean work achieved by acetazolamide group was $63 \%$ of sea level value whereas in placebo group it was $55 \%$ of sea level value. The decrease in performance at altitude of the placebo group was significantly greater than that of the acetazolamide group $(P<0.05)$.

\section{Reference}

Bradwell, A.R., Dykes, B.W., Coote, J.H. et al. Effect of acetazolamide on exercise performance and muscle mass at high altitude. Lancet 1986, i: 1001-1005.

\section{Changes in serum and urinary purines at high altitude (Abstract)}

\author{
P.J.G. Forster, H.J. Rylance, R.C. Wallace and G. Nuki
}

University of Edinburgh, Rheumatic Diseases Unit, Northern General Hospital, Ferry Road, Edinburgh EH5 2DQ, $U K$.

Ascent to high altitude causes hypoxia and respiratory alkalosis and may lead to acute mountain sickness. Acetazolamide ameliorates the symptoms of acute mountain sickness by increasing renal bicarbonate excretion and inducing a relative metabolic acidosis thus stimulating central respiratory drive with a resultant increase in arterial oxygen tension.

Using high pressure liquid chromatography, serum and urine purines have been measured in 20 subjects climbing to $2896 \mathrm{~m}$ and $4846 \mathrm{~m}$ in the Himalayas. Ten subjects (9 males, 1 female) took acetazolamide $500 \mathrm{mg} /$ day and a matched group were placebo controls. Serum urate, xanthine and total purines were not significantly different at the two altitudes or between the treatment groups and 24 hour urate, xanthine and total purine excretion were not altered. However, serum hypoxanthine levels were significantly raised in both placebo $(37 \pm 11 \mu \mathrm{mol} / \mathrm{l})$ and acetazolamide $(46.4 \pm 14.7 \mu \mathrm{mol} / \mathrm{l})$ treated subjects at $4846 \mathrm{~m}$ elevation, compared with $2986 \mathrm{~m}$ (control $20 \pm 6.6 \mu \mathrm{mol} / \mathrm{l}$; acetazolamide $32 \pm 13 \mu \mathrm{mol} / \mathrm{l})$ and this increase was associated with significant decreases in hypoxanthine clearance $(\mathrm{ml} / \mathrm{min})(2896 \mathrm{~m}$ control $5.9 \pm 4.3$, acetazolamide $2.2 \pm 1.1 ; 4800 \mathrm{~m}$ control $1.7 \pm 1.3$, acetazolamide $0.8 \pm 0.6$ ).

Although the increase in blood $\mathrm{H}^{+}$concentration induced by acetazolamide at high altitude does stimulate central respiratory drive, the resulting concentration is less than at sea level and insufficient to influence urate clearance. By contrast, serum hypoxanthine is increased both by high altitude and acetazolamide and this appears to be associated with impaired renal excretion rather than breakdown of tissue nucleotides caused by exercise or hypoxia. 